\title{
GISを活用した地震損害評価 DEVELOPMENT OF GIS-AIDED LOSS システムの構築 \\ ESTIMATION SYSTEM FOR \\ EARTHQUAKE HAZARD
}

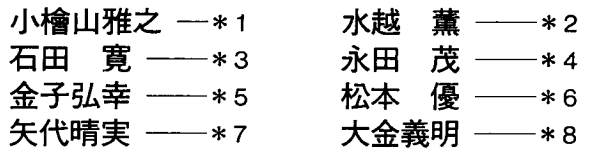

キーワード :

地理情報システム，地震動，液状化，地震火災，地震被害，保険

Keywords :

GIS, Earthquake motion, Liquefaction, Earthquake-triggered fire, Earthquake damage, Insurance

Masayuki KOHIYAMA $-* 1$
Hiroshi ISHIDA $-* 3$
Hiroyuki KANEKO $* 5$
Harumi YASHIRO $-* 7$

Kaoru MIZUKOSHI $* 2$
Shigeru NAGATA $* 2$
Masaru MATSUMOTO - $* 6$
Yoshiaki OGANE

A loss estimation system for earthquake hazard capable of evaluating all of Japan was developed. A GIS (Geographic Information System) for personal computers is utilized for this system, which assists in interactive selection of the assumed earthquake and representation of the estimated results on a computer screen. Source parameters of the assumed earthquake can be derived from a database of active faults and historical earthquakes.

Earthquake ground motion, liquefaction and earthquake-triggered fire are considered in order to estimate building damage ratios. An insurance company's exposure can quickly be estimated by linking this system to an insurance contract database.

\section{1.はじめに}

広域の地震被害評価は膨大な種々のデータベースが必要となり， またその計算量も非常に大きなものとなるが, 近年, 情報処理関連 分野の急速な進歩により，パソコン上でも十分実用的な速度で計算 し結果を表示するシステムを構築することが可能となった。著者ら は，日本全国を対象として歴史地震の再現や様々な想定地震による 建物被害率を評価し，損害保険会社の保険契約データとリンクさせ ることにより支払保険金額を即座に推定するシステムを開発した。 本報告では, 地震損害評価手法およびシステム構成について既要を 述べる。

\section{2. システム概要}

本システムは図 1 に示すようにパソコン用地理情報システム（G I S ）をべースにシミュレーション処理系であるプログラムモジュ ールとデータベース（D B ）から構成される。地震動強さから地震 被害までの評価は標準地域メッシュ1)の第 3 次地域区画（3 次メッ シュ）単位で行い, 支払保険金額の評価は市区郡単位で行う。評価 の概略フローを図 2 に示す。

\footnotetext{
*1 鹿島建設侏技術研究所先端技術研究部 研究員 - 工修

（テ182-0036 調布市飛田給2-19-1)

*2 鹿島建設(侏技術研究所先端技術研究部 グループ長・工博

*3 鹿島建設(侏技術研究所先端技術研究部 主管研究員 -工修

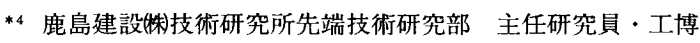

*5 鹿島建設侏技術研究所企画管理室 研究員 ·工修

*6 東京海上火災保険( リスクマネジメント業務部 火災グループリーダー・ 工修

*7 東京海上リスクコンサルティング侏第一事業部 課長・工修

*8 東京海上リスクコンサルティング侏第一事業部 主任・工修
}

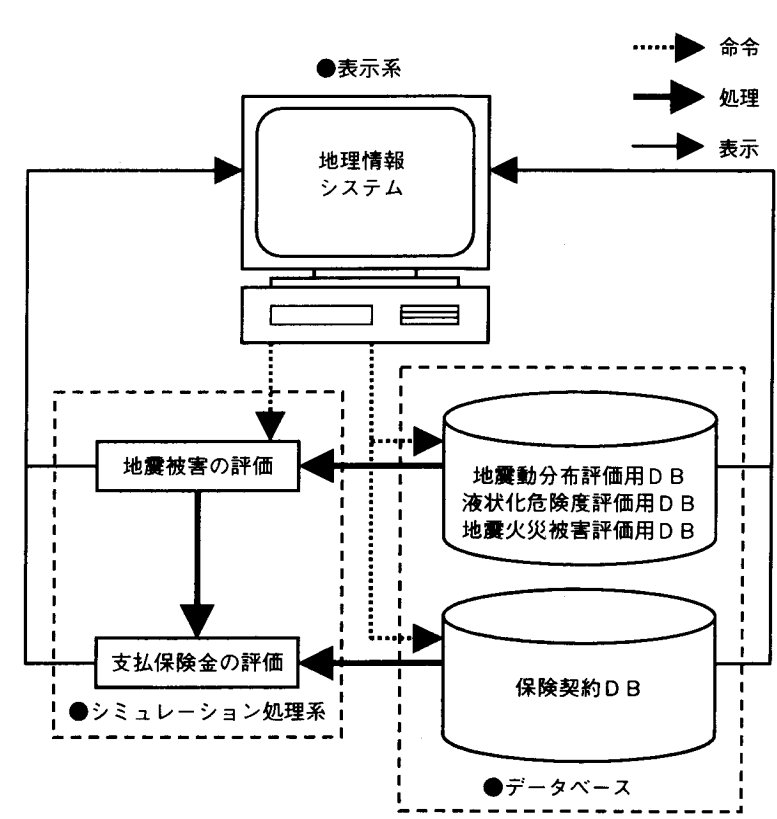

図 1 地震損害評価システムの構成

*1 Research Engineer, Kajima Technical Research Institute, Advanced Technorogy Department, M. Eng.

*2 Group Manager, Kajima Technical Research Institute, Advanced Technorogy Department, Dr. Eng.

*3 Chief Research Engineer, Kajima Technical Research Institute, Advanced Technorogy Department, M. Eng.

*4 Senior Research Engineer, Kajima Technical Research Institute, Advanced Technorogy Department I, Dr. Eng.

*5 Research Engineer, Kajima Technical Research Institute, Planning and Administration Office, M. Eng.

*6 Manager, THE TOKIO MARINE AND FIRE INSURANCE CO., LTD., Risk Management Department, Property Risk Group M. Eng.

*7 Manager, THE TOKIO MARINE RISK CONSULTING CO., LTD., Property Division M. Eng.

*8 Assistant Manager, THE TOKIO MARINE RISK CONSULTING CO. LTD., PROPERTY DIVISION M. Eng. 


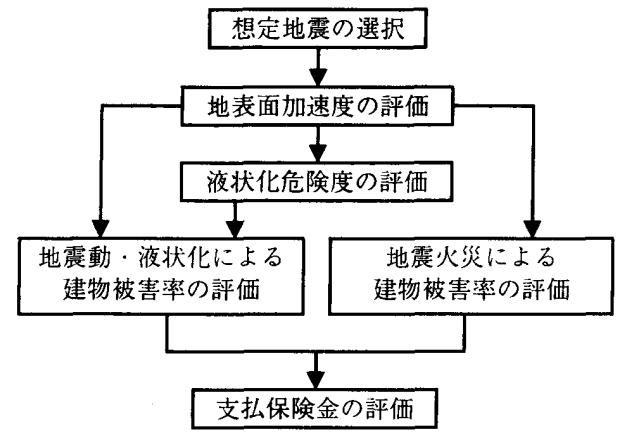

図 2 地震損害評価の概略フロー図

\section{3. 地露動分布の評価}

本システムでは点震源と面震源の 2 種類の震源モデルを用いるこ とができ, 歴史地震および活断層のデータベースから G I S の機能 を活用して対話的に想定地震のパラメータを設定することができる。

各メッシュ重心位置の基盤面（せん断波速度 $600 \mathrm{~m} / \mathrm{s}$ 以上）の最 大加速度 $A_{b}$ の大きさは以下の距離隇衰式) で与えられる。

$\log A_{b}=0.318 M_{w}-\log X_{e q}-0.00164 X_{e q}+1.597$. . (1)

$$
\text { ここで } M_{w}: \text { モーメントマグニチュード }
$$

$X_{e q}$ : 等価震源距離 $(\mathrm{km})$

$X_{e q}$ は震源断層の特定が困難な歴史地震などの場合は (2) 式, 震 源断層の形状が与えられる場合は（3）式で与えられる。（3）式に ついては震源からのエネルギー放出分布は一様と仮定し断層面を小 領域に分割して計算を行う。

$$
\begin{aligned}
& X_{\text {eq }}=\frac{R}{\sqrt{\ln \left(1+\left(\frac{R}{X}\right)^{2}\right)}} \ldots \ldots \ldots(2) \\
& X_{e q}=\sqrt{n / \sum_{i=1}^{n} X_{i}^{-2}} \ldots \ldots \ldots(3) \\
& \text { ここでR：マグニチュードから求めた震源域面積3)を持つ } \\
& \text { 円形震源の半径 }(\mathrm{km}) \\
& X: \text { 震源距離 }(\mathrm{km}) \\
& n: \text { 断層面の小領域の数 } \\
& X_{i}: i \text { 番目の小領域と観測地点との距離 }(\mathrm{km})
\end{aligned}
$$

翠川ら ${ }^{4)}$ は 1987 年千葉県東方沖地震 $(M J M A 6.7)$ の観測結果をも とに，地盤分類ごとの距離隇衰式を求めた。これによる第三紀以前

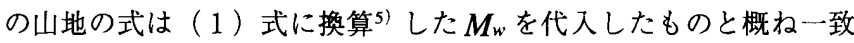
することが確認された。よって第三紀以前の山地の式に対する他の 地盤分類の式の比を基盤面最大加速度加ら地表面最大加速度への增

表 1 最大加速度增幅率

\begin{tabular}{|c|c|c|}
\hline 地質年代 & 地形分類 & 最大加速度増幅率 \\
\hline 第三紀以前 & 山地 & 1 \\
& 丘陵地 & 1.45 \\
\hline \multirow{3}{*}{ 洪積世 } & 丘陵地 & 1.86 \\
& 口-㕕台地 & 1.78 \\
& 砂碟台地 & 2.14 \\
\hline \multirow{3}{*}{ 沖積世 } & 扇状地 & 1.74 \\
& 三角州 & 2.24 \\
& 砂州・自然堤防 & 2.34 \\
\cline { 2 - 3 } & 埋め立て地 & 2.34 \\
\hline
\end{tabular}

幅率とみなし（表 1)，国土数值情報1)の表層地質・地形分類を用い て各メッシュの増幅率を設定した。地表面最大加速度はこの増幅率 を（1）式で求めた基盤面最大加速度に乗じて求められる。

\section{4. 液状化危険度の評価}

三浦ら ${ }^{6)}$ は河川周辺の液状化危険度を定性的に予測する手法を提 案した。本システムでは三浦らの手法に海岸や湖沼周辺の液状化危 険度の評価を追加し，さらに松岡・翠川ら ${ }^{7 / 8)}$ の国土数值情報を基 にした地形分類法を一部導入して液状化危険度の判定を行う。液状 化危険度判定フローを図 3 に示す。

判定手順はまず国土数值情報の表層地質・地形デー夕をもとに各 メッシュの地形分類を行い, 三浦ら ${ }^{6)}$ の論文を参考に作成した表 2 に基づき液状化限界加速度 $A_{c}$ 求める。次に地表面最大加速度 $A_{\text {max }}$ と比較し液状化の可能性の有無を判定し, 河川および海・湖 沼の水涯線からの距離ならびに水位と評価地点の標高差から表 $3 に$ 示した考え方に基づき河川，海・湖沼それぞれに関して液状化危険 度を判定する。ここで河川の場合は, 国土数值情報の流路位置ファ イルで最も近傍の河川の河床標高と評価地点の平均標高との差を標 高差とした。表 3 は河川に関するものは三浦ら 6) の論文を参考に作 成し, 海・湖沼に関するものは 1995 年兵庫県南部地震の被害データ

\begin{tabular}{|c|c|c|c|c|}
\hline & \multicolumn{3}{|c|}{ 離岸距離L } \\
\hline & & $\overline{\mathrm{L}<\mathrm{L}_{1}}$ & $\mathrm{~L}_{1} \leqq \mathrm{~L}<\mathrm{L}_{2}$ & $\overline{L_{2}} \leqq L$ \\
\hline \multirow{3}{*}{ 標高差H } & $\mathrm{H}<\mathrm{H}_{1}$ & 危険度大 & \multirow[b]{2}{*}{ 危険度中 } & \multirow[b]{3}{*}{ 危険度小 } \\
\hline & $\mathrm{H}_{1} \leqq \mathrm{H}<\mathrm{H}_{2}$ & & & \\
\hline & $\mathrm{H}_{2} \leqq \mathrm{H}$ & & & \\
\hline
\end{tabular}
9) 10)をもとに作成した。最後に評価地点の液状化危険度は図 3 に示 す $\mathrm{DR}_{\mathrm{R}}$ と $\mathrm{Ds}$ の 2 つの危険度を比較し高い方とする。

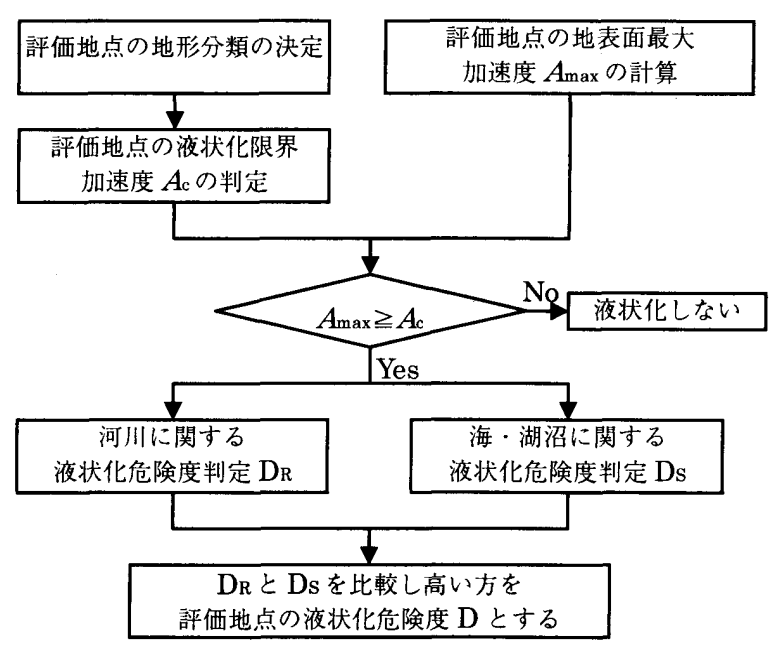

図 3 液状化危険度判定フロー図

表 2 液状化限界加速度

\begin{tabular}{|c|c|}
\hline 地形分類 & 液状化限界加速度 (Gal) \\
\hline 人工地盤 & 80 \\
自然堤防 - 旧河道 & 90 \\
三角州性低地 & 100 \\
扇状地性低地 & 120 \\
扇状地 & 300 \\
\hline
\end{tabular}

表 3 液状化危険度判定の考え方注 1) 


\section{5．地震動・液状化による建物被害の評価}

地震動・液状化による建物被害は建物構造（木造／非木造) ・ 被害 レベル11) (全損 /半損/一部損) 別に建物被害率 $R_{\mathrm{d}} に よ り$ 評価する。 $R_{\mathrm{d}}$ はメッシュ内に存在する建物の被害率を表し,木造全損率の場合， （木造全損棟数／木造全棟数）を表す。 $R_{\mathrm{d}}$ は地表面最大加速度 $A \max$ の関数 $\mathrm{F}_{\mathrm{d}}\left(A_{\max }\right)$ と液状化危険度 $\mathrm{D}$ の関数 $\alpha_{\mathrm{d}}(\mathrm{D})$ により次式 で与えられるものと仮定した。

$$
R_{\mathrm{d}}=\alpha_{\mathrm{d}}(\mathrm{D}) \mathrm{F}_{\mathrm{d}}\left(A_{\max }\right) \quad \ldots . . . . . .(4)
$$
ここで $\mathrm{F}_{\mathrm{d}}\left(A_{\mathrm{max}}\right)$ は 1995 年兵庫県南部地震ならびに近年の 5 地震の 地震動による建物被害デー夕12）13）14）をもとに求めた建物フラジリ ティ曲線（図 4）であり，上記被害デー夕における全壊・半壊・一部 損壊はそれぞれ全損・半損・-一部損と同等の被害レベルであると仮 定した。また $\alpha_{\mathrm{d}}(\mathrm{D})$ は液状化による被害率割增係数であり，兵庫県 南部地震の液状化による建物被害デー夕10) より求めた。

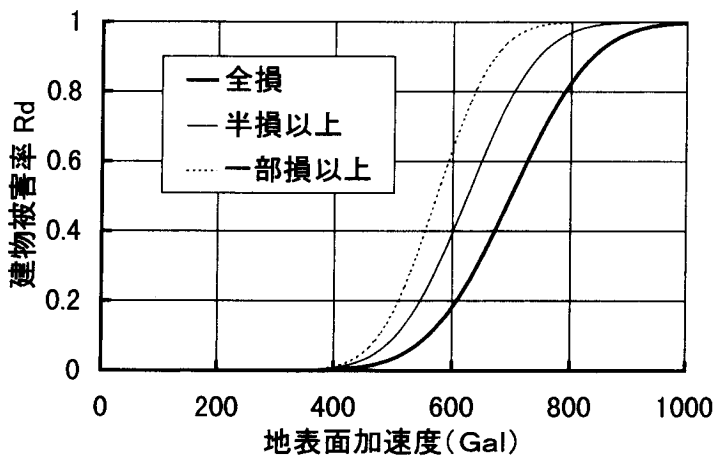

図 4 建物フラジリティ曲線（木造建物）

\section{6. 火災による建物被害の評価}

従来の焼失率の評価は, 出火点を想定後, 延焼速度式を評価して 逐次的に延焼範囲を求める決定論的な評価モデルであり，今回のよ うな広域の被害推定には不向きであった。そこで本システムでは, ある限界点以上に木造建物が集積する地域では急激に延焼危険性が 増大する現象をモデル化することで該当地域の焼失確率をより簡便 に推定できる確率論的モデル15)を採用した。

本システムでは火災による建物被害は焼失率 $R_{F}$ （焼失棟数／全 棟数）により評価する。焼失率評価フロー図を図 5 に示す。

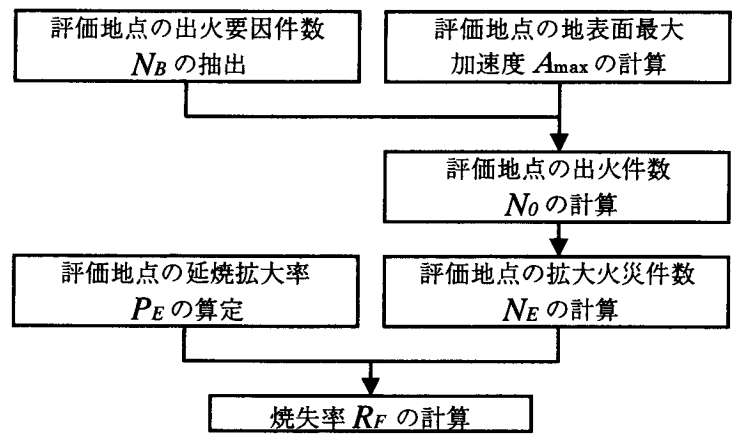

図 5 焼失率評価フロー図

出火件数 $N_{0}$ の推定は次式で表される東京消防庁による方法 ${ }^{16)}$ 用いる。

$$
\begin{aligned}
& N_{o}= \sum_{B} P_{B}(A \max ) N_{B} \cdots \cdots \cdots \\
& \text { ここで } \quad B: \text { 出火要因の種類 } \\
& \\
& \\
& \quad N_{B}: \text { 出火要因件数 } \\
& P_{B}\left(A_{\max }\right): \text { 出火確率 }
\end{aligned}
$$

評価地点における住宅, 飲食店等の種々の $N_{B}$ は国勢調査, 事業 所統計調査のメッシュ統計データ17)を用いて推計しデータベース化 した。 $P_{B}\left(A_{\text {max }}\right)$ は地表面最大加速度 $A_{\text {max }}$ により出火時間帯別の出 火確率テーブルで与えられる。

上記の $N_{0}$ はほ中や・小損を含む全出火を対象とするため，広域的 な火災被害を評価するために大火に発展する出火件数を算定する必 要がある。そこで延焼規模 50 軒以上の出火件数を拡大火災件数 $N_{E}$ とし, 出火件数加拡大出火件数を求める式を兵庫県南部地震の被 害データ18）19) から以下の回帰式により求めた。

$$
\begin{aligned}
& N_{E}=\frac{a_{3}}{1+e^{a_{1} N_{0}+a_{2}}}-a_{4} \\
& \text { ここで } a_{i}: \text { 回帰係数 }
\end{aligned}
$$

焼失率 $R_{F}$ は次式で評価する。

$$
\begin{aligned}
& R_{F}=b P_{E} N_{E} \\
& \text { ここで } \quad b: \text { 補正係数 } \\
& \\
& P_{E}: \text { 延焼桩大率 }
\end{aligned}
$$

本手法では焼失率 $R_{F}$ は拡大火災件数 $N_{E}$ に比例するものと仮定 した。 $P_{E}$ はメッシュ内の拡大火災件数 1 軒に対する焼失率を表し, 金子ら ${ }^{15)}$ の手法により全国のメッシュについて評価を行いデータベ 一ス化した。上記手法は木造率等の建物構造比率のデータが不十分 な地域でも評価できるように国勢調查，事業所続計調査のメッシュ 統計デー夕17) を用いて延焼危険性に関わる地域特性を指標化し，実 際に延焼危険度の評価ができる地域と対比して延焼拡大率を求める ものである。補正係数 $b$ は安全率等を考慮し別途定める係数とする。

\section{7. 支払保険金額の算定}

支払保険金額の算定にあたり，まず保険契約データベースが市区 郡単位で集計されていることを考虑し 3 次メッシュ単位で求めた各 建物被害率について重み付き平均を行い各市区郡の被害率を求める。 この被害率を用いて各市区郡ごとに保険契約データベースを参照し 契約件数に被害率を乗じて各被害状況に対する被害棟数の評価を行 い支払保険金額の算定を行う。

\section{8. 評価事例}

図 6〜9に 1995 年兵庫県南部地震の面震源断層モデルを想定地 震とした場合の被害評価結果を図示する。出火時間帯は東京消防庁 による方法 ${ }^{16)}$ では夏または冬の昼または夜を想定しており，ここで はより大きな出火件数が予想される冬の日の夜を想定した。また， 上記地震による実際の観測值ならびに被害を表す図として, 図 10 に地表面最大加速度観測値 ${ }^{20)}$ (水平成分), 図 11 に液状化率 ${ }^{10)}$ (各 メッシュ面積に対する噴砂領域の面積の比), 図 12 に町丁目ごとの 非堅牢建物全壊率21）（木造全損率とほほ同等とみなせる）, 図 13 に 神戸市 6 区の焼失率22）を示す。 


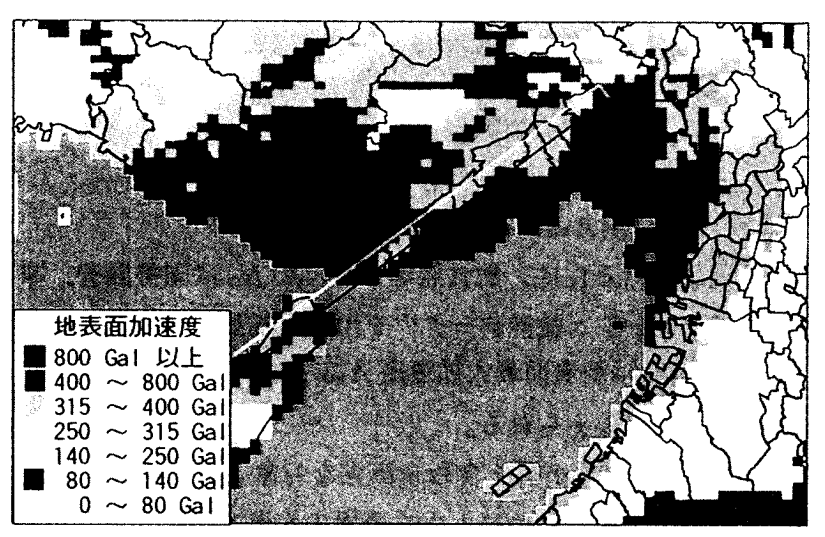

図 6 地表面最大加速度の評価結果

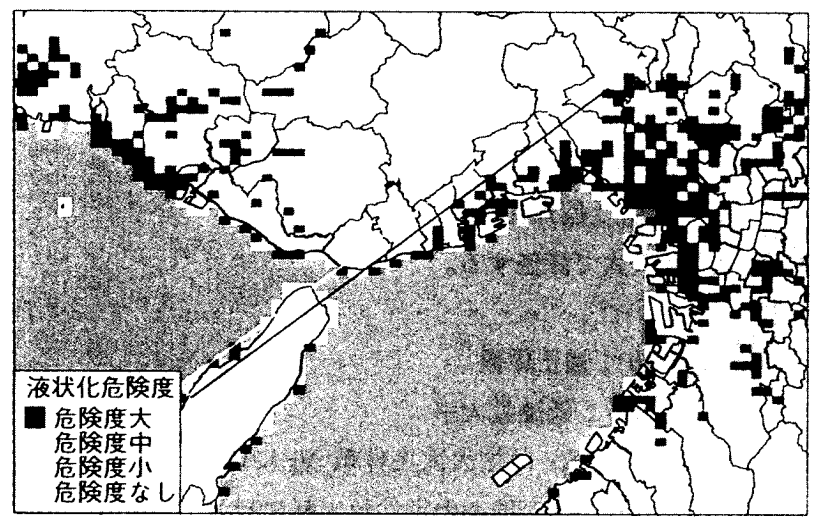

図7 液状化危険度の評価結果

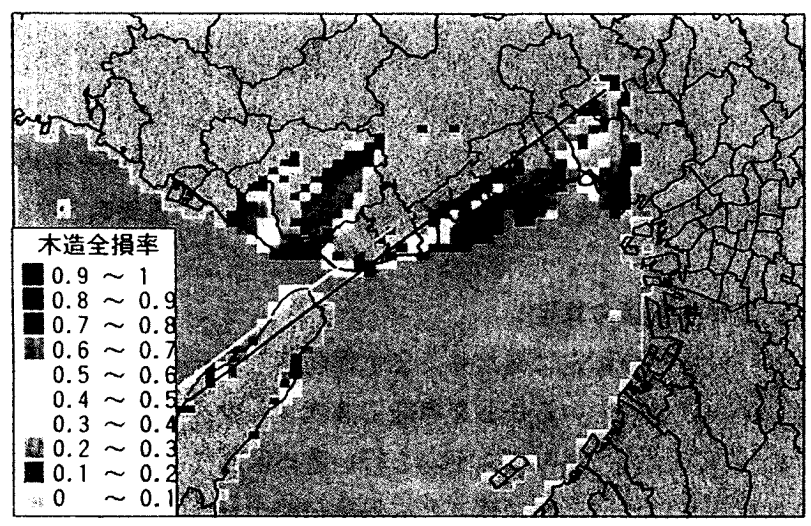

図8 木造建物全損率の評価結果

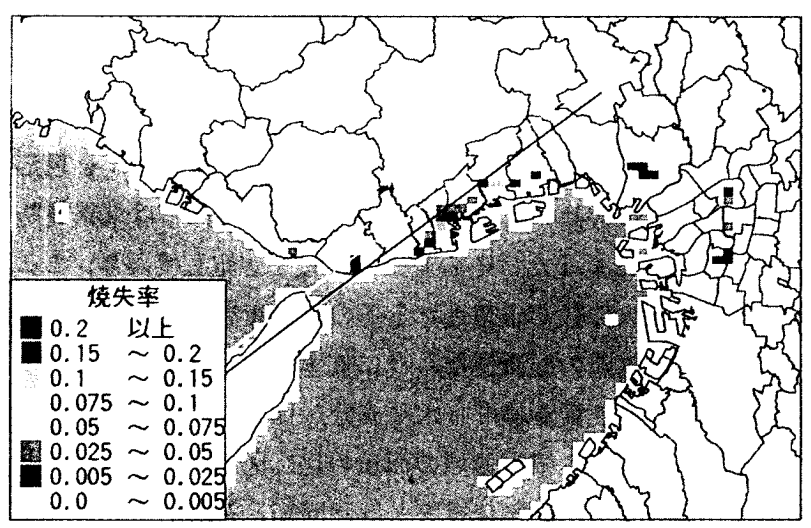

図 9 焼失率の評価結果

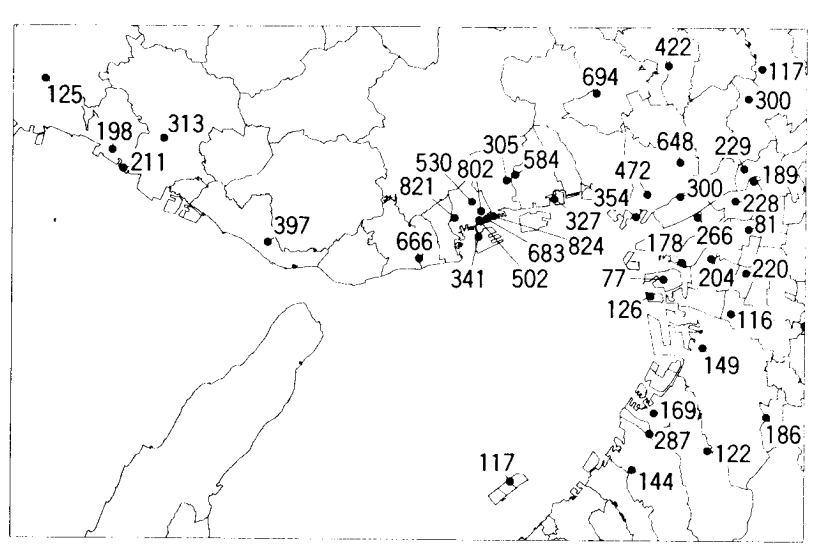

図 10 兵庫県南部地震における地表面最大加速度201

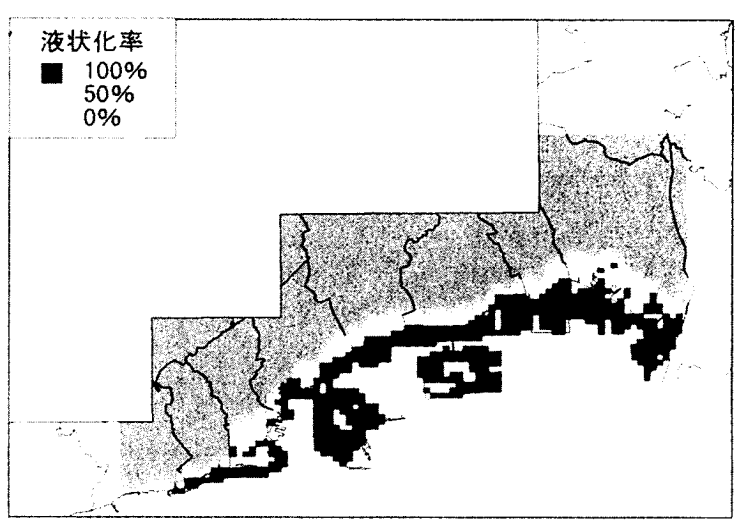

图 11 兵庫県南部地震に扔ける液状化率(10)

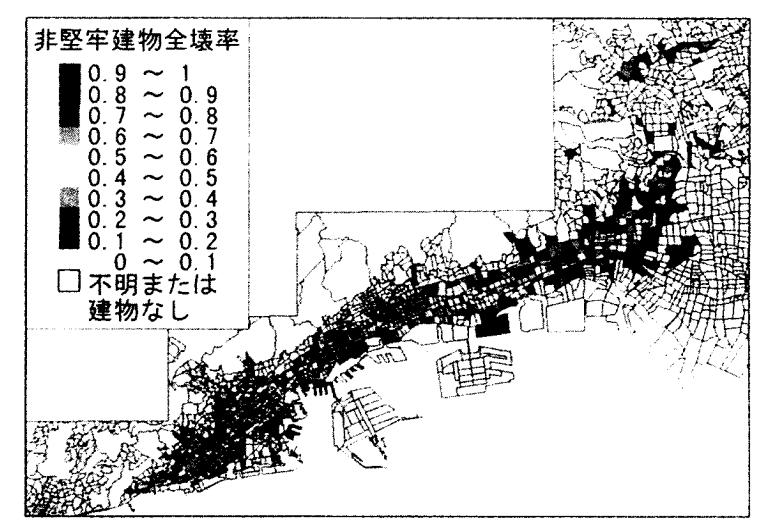

図 12 兵庫県南部地震における非堅牢建物全壊率21) 注2

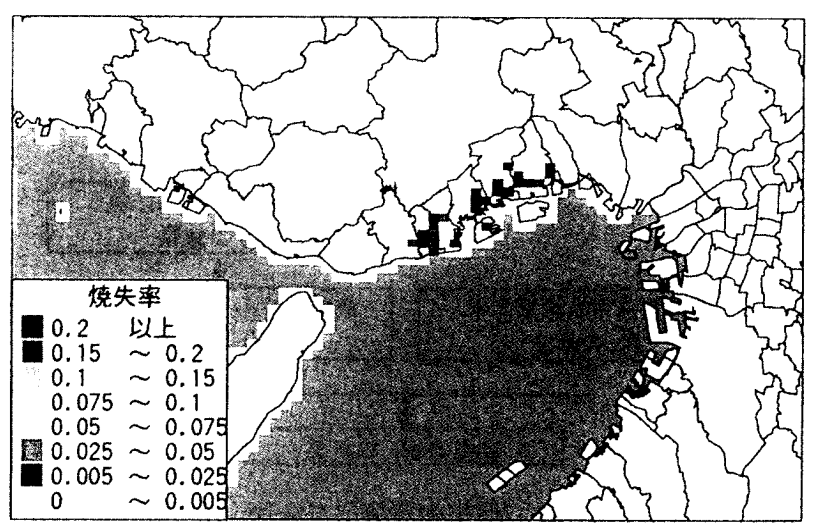

図 13 兵庫県南部地震に扔ける神戸市 6 区の焼失率 221 
シミュレーション結果と実際の観測值, 被害率分布を以下に比較 考察する。地表面最大加速度については概ね整合した評価となって いる。誤差が生じている地点では原因として 3 次メッシュの解像度 に起因する地盤種別の違いが考えられる。大阪湾岸で過大評価とな っている原因としては臨海部に顕著に見られた液状化等による表層 地盤の非線形性を考慮していないことが挙げられる。Ohno et $\mathrm{al}^{2 /}$ に よれば（1）式は兵庫県南部地震に扮ける岩盤上の観測記録によく 対応し，洪積層，沖積層上の観測記録は平均的にそれぞれ $1.4,1.8$ 倍となっている。一方,本システムで設定した増幅率はそれぞれ 1.78 ～2.14，1.74〜2.34 と大き目である。これは，兵庫県南部地震では非 線形効果が比較的大きいのに対し，千葉県東方沖地震ではあまり非 線形効果が含まれていないため4) と考えられる。今後, 評洒精度を 向上させるためには非線形効果を考慮した増幅特性を用いる必要が ある。

液状化危険度の評価については，マクロに見た場合，本システム は実際に液状化した地域に比べ液状化発生の危険度がある領域を広 めに評価する傾向がある。一方，神戸市周辺の上うに海岸線部から 山側にかけて標高が急変する地域では水位標高差を過大に評価する ために海沿いの人工地盤に㧈ける液状化危険度は逆に低めに評価さ れており, 評価単位の解像度が原因となっている。また，広範囲の 埋立地においては離岸距離により液状化危険度が評価されるため同 じく過小評価される傾向がある。

木造全損率については臨海部等で過大評価となっている。原因と しては表層地盤の非線形性を考虑していないことなど地震動の過大 評価が考えられる。また，建物フラジリテイ曲線の作成に用いた被 害データのサンプル数が少ないことによる䛊差の影響もあり,今後, 広範な被害統計デー夕を補うことで評価精度の向上を目指す必要が ある。

焼失率については, 実際の地震発生が早朝でありシミュレーショ ンで想定した夜ではないため, 飲食店等の出火件数に誤差が含まれ る。また，前述した地震動分布の䛊差も出火件数に影響を及ほす。 評価事例ではこの誤差がそれほど大きくないものとして，神戸市全 体の焼失被害傾向を表すよう補正係数 $b$ を設定した場合の評価結果 を示している。今後の課題として延焼に深く関わる気象条件や消防 活動といった因子の考慮があげられる。

\section{9.おわりに}

本システムは歴史地震や活断層等による地震に対する建物被害を 評価し，損害保険会社の支払保険金額の算定をパソコン上で行うこ とができる。G I S の活用により評価結果は地図上にわかりやすい 形で表示することが可能である。今後，本システムの被害評価精度 を向上させるための課題として, 地震動強さの評価における地盤の 非線形性の考慮, より多くの被害デー夕に基づく建物フラジリティ 曲線等の各種パラメータの評価, 評価単位の解像度に対する検討, 延焼火災被害における気象条件の考慮等が挙げられる。

\section{参考文献}

1) 建設省国土地理院：数值地図ユーザーズガイド，(財）日本地図セン夕 一, 1992 年

2) Ohno, S. et al : Intensity of Strong-Motion on Pre-Quaternary Stratum and
Surface Soil Amplifications during the 1995 Hyogo-Ken Nanbu Earthquake, Japan, J.Phys.Earth., Vol.44, pp.623-648, 1996

3) Sato, R. : Theoretical Basis on Relationships between Focal Parameters and Earthquake Magnitude, J.Phys.Earth., Vol.27, pp.353-372, 1979

4) 翠川三郎, 松岡昌志, 作川孝- - 1987 年-千葉県東方沖地震の最大加速度 . 最大速度にみられる地盤特性の評価, 日本建築学会構造系論文報告集， 第 442 号, pp.71-78, 1992.12

5）武村雅之：日本列島およびその周辺地域に起こる浅発地震のマグニチュ 一ドと地震モーメントの関係, 地震, 第 2 輯, 第 43 巻, pp.257-265, 1990.6

6）三浦房紀汪か 3 名：液状化危険地域の簡易推定法，第 9 回日本地震上学 シンポジウム論文集, pp.1015-1020, 1994 年

7）松岡昌志，翠川三郎，若松加寿惠：国土数值情報を利用した㳎域液状化 危険度予測，日本建築学会構造系論文報告集，第 452 号,pp.39-45, 1993.10

8）翠川三郎，松岡昌志：国土数值情報を利用した地震ハザードの総合的評 価, 物理探査, 第 48 巻, 第 6 号, pp.519-529, 1995 年.

9）濱田政則，磯山龍二，若松加寿恵：1995 年兵庫県南部地震 液状化，地 盤変位及び地盤条件，(財) 地震予知総合研究振興会，1995 年

10）（社）日本水道協会：1995 年兵庫県南部地震による水道管路の被害と分 析, 1996 年

11）（社）日本損害保険協会：地震保険損害査䇥指針，1991年

12）早坂浩ほか 5 名：兵庫県南部地震による建物被害の分析その1 研究概 要と建物属性分析, 日本建築学会大会学術講演梗概集, pp.1-2, 1996 年

13）嘉島蒿志ほか 5 名：兵庫県南部地震による建物被㫪の分析その 2 建物 フラジリティ曲線，日本建築学会大会学術講演梗概集，pp.3-4，1996 年.

14）童華南ほか3名：被害事例に基づく地震動強さと家屋被害率の関係，第 9 回日本地震工学シンポジウム論文集, pp.2299-2304, 1994 年

15）金子弘幸，佐藤博臣：地域特性を考慮した都市火災シミュレーションの 提案, 日本火災学会平成 8 年度研究発表会梗概集, pp.80-83, 1996 年

16）東京消防庁：地震時に打ける地域別の総合出火危険予測上対策, 1987 年

17）総務庁統計局：地域メッシュ統計の概要，(財) 日本統計協会，1994年

18）鈴木恵子, 松原美之：1995 年兵庫県南部地震後10日間の出火状況, 消 研輯報第 49 号, 1995 年.

19）室崎益輝, 神戸大学室崎研究室他：阪神・淡路大震災時の火災の延焼状 況調査報告書, 1995 年

20）日本建築学会兵庫県南部地震特別研究委員会，日本建築学会近畿支部矿 震構造研究部会：1995 年兵庫県南部地震強震記録資料集, 1996 年

21）建設省建築研究所：平成 7 年兵庫県南部地震被害調査最終報告書, 1996 年

22）金子弘幸，佐藤博臣：メッシュ解析による出火·延焼拡大に関する考察， 日本火災学会平成 9 年度研究発表会梗概集, pp.212-215, 1997 年

注

注 1）危険度判定の境界值 $\mathrm{H}_{1}, \mathrm{H}_{2}, \mathrm{~L}_{1}, \mathrm{~L}_{2}$ は, 河川, 海・湖沼に対し別々に 与える。

注2）図11，120地図は建設省建築研究所が建設省国土地理院の承認老 得て, 同院発行の数值地図 10000 (総合) を複製したCD-ROM データ に基づいて作成したものである。(承認番号 平 8 棇複，第 26 号）。

[1998年 6 月26日原稿受理 1998年11月 4 日採用決定］ 